\title{
IMPLENTASI SURAT KEPUTUSAN DIREKTUR RUMAH SAKIT UMUM DAERAH KABANJAHE TENTANG KAWASAN TANPA ROKOK
}

\author{
Seriusman H. Sitanggang, Juanita, Raden Kintoko Rochadi \\ Fakultas Kesehatan Masyarakat Universitas Sumatera Utara
IMPLEMENTATION OF THE DECREE OF KABANJAHE GENERAL HOSPITAL DIRECTOR CONCERNING NON-SMOKING AREA

\begin{abstract}
Background: The case of smoking today becomes a big problem which can cause death in Indonesia. Law /No. 44/2009 on Hospital require hospital management impose a regulation that all areas of a hospital have to be KTR (No Smoking Area). Kabanjahe Regional General Hospital has implemented the policy of KTR according to the SK (Directive) of the Hospital which has not been implemented completely so far. The objective of this research was to analyze the implementation of SK Director RSU Kabanjahe No. 1255/RSU/2016 About KTR at RSU Kabanjahe in 2017.

Metode: This research used qualitative method with interview technique, participant observation, documentation and triangulation with sample consisting of 4 employees and 2 patients of Kabanjahe Hospital and using note book instrument, tape recorder, camera and researcher as instrument. The belief in the results of the research is done by testing the credibility, depenability, process and research results. The research was conducted in RSUD Kabanjahe.

Result: The result of the research showed that the implementation of KTR at RSU Kabanjahe did not run well although it had been implemented for eight years. It was caused by some inhibiting factors such as some of its managers and the personnel still smoked, there was no Regional Regulation which regulated it, there was the lack of commitment of the Director in imposing sanction and in establishing a supervisory committee for KTR.

Conclusion: The implementation of KTR at Kabanjahe Hospital was not in accordance with the Directive of the Director of the hospital or failed. It is recommended that the hospital management increase disposition, and bureaucratic structure in supporting the policy on KTR.

Keywords: non smoking area, implementation, hospital
\end{abstract}

\begin{abstract}
ABSTRAK
Latar Belakang: Masalah rokok pada saat ini sudah menjadi masalah besar yang menyebabkan kematian di Indonesia. UU No. 44/2009 Tentang Rumah Sakit (RS) menyebutkan setiap RS mempunyai kewajiban memberlakukan seluruh lingkungan RS sebagai Kawasan Tanpa Merokok (KTR). RS Umum Daerah (RSUD) Kabanjahe telah menerapkan KTR sesuai SK direktur RS namun sejauh ini pelaksanaannya belum berhasil. Tujuan penelitian ini untuk menganalisis pelaksanaan SK Direktur RSUD Kabanjahe No. 1255 / RSU / 2016 Tentang penerapan KTR di RSUD Kabanjahun tahun 2017.

Metode: Penelitian ini menggunakan metode kualitatif dengan teknik wawancara, observasi berperan serta, dokumentasi dan triangulasi dengan sampel terdiri dari 4 orang pegawai dan 2 orang pasien RSUD Kabanjahe dan menggunakan instrumen buku catatan, tape recorder, kamera dan peneliti sebagai instrumen. Kepercayaan terhadap hasil penelitian dilakukan dengan pengujian kredibilitas, depenabilitas, proses dan hasil penelitian. Penelitian dilakukan di RSUD Kabanjahe.

Hasil Penelitian: Hasil penelitian menunjukkan bahwa penerapan KTR di RSUD Kabanjahe belum berjalan dengan baik walaupun telah dilaksanakan selama delapan tahun. Hal ini dikarenakan beberapa faktor penghambat seperti Direktur RS dan jajarannya masih merokok, tidak ada perda yang mengatur tentang KTR, tidak adanya komitmen Direktur dalam menjatuhkan sanksi dan membentuk komite pengawas KTR. Kesimpulan: Penerapan KTR di RSUD Kabanjahe belum sesuai dengan SK Direktur atau belum berhasil. Pimpinan rumah sakit diharapkan dapat meningkatkan disposisi, dan struktur birokrasi dalam mendukung kebijakan KTR.
\end{abstract}

Kata Kunci: Kawasan tanpa rokok; implementasi; rumah sakit

Alamat Koresponding: Seriusman H. Sitanggang, Fakultas Kesehatan Masyarakat Universitas Sumatera Utara, Jl. Universitas, No. 21, Kampus USU Medan 20155, email : seriusmansitanggang@gmail.com 


\section{PENDAHULUAN}

Masalah rokok di Indonesia saat ini sudah menjadi masalah besar penyebab angka kematian nasional. WHO mengadakan Sidang Majelis Kesehatan Dunia ke 56 pada bulan Mei 2003 yang dihadiri 191 negara anggota dari WHO, dengan suara bulat mengadopsi Kerangka Kerja Konvensi Pengendalian Tembakau/Framework Convention on Tobacco Control (FCTC). FCTC ini berlaku efektif sejak tanggal 27 Februari 2005. Pemerintah mempunyai kewajiban dan kewenangan untuk melindungi masyarakat, dan yang merupakan pokok-pokok kebijakan FCTC seperti peningkatan cukai, larangan iklan menyeluruh, penerapan KTR, peringatan kesehatan dalam bentuk gambar, program berhenti merokok dan pendidikan masyarakat1. Namun, Indonesia hingga saat ini menjadi satu-satunya negara di Asia Tenggara yang belum menjadi peserta FCTC. Rata-rata perokok menghabiskan 10-11 batang per hari di tahun $2004 .^{1}$

Hasil survei Badan Kesehatan Dunia tahun 2013, menyatakan bahwa sepertiga kaum pria berusia di atas 15 tahun atau berkisar 1,35 miliar orang penduduk di dunia memiliki kebiasaan merokok dan dari jumlah tersebut sebanyak 250 juta adalah perempuan, dimana $80 \%$ diantaranya tinggal di negaranegara berkembang dengan penghasilan rendah dan sedang, serta diprediksi mereka menghabiskan lebih dari 5 triliun batang rokok dalam setahun. ${ }^{2}$ Rumah sakit sebagai institusi pelayanan kesehatan sudah seharusnya memiliki lingkungan yang bersih dan sehat, termasuk bebas dari asap rokok. Namun kenyataannya masih sering dijumpai orang-orang merokok di lingkungan rumah sakit. Untuk menciptakan lingkungan yang bersih dan sehat serta bebas dari asap rokok maka pemerintah merujuk UU No. 44 tentang Rumah Sakit tahun $2009,{ }^{3}$ serta UU No. 36 tahun 2009 tentang kesehatan (UU RI Nomor 32 Tahun 2009 Tentang Perlindungan Pengelolaan Lingkungan Hidup). ${ }^{4}$ Direktur
RSUD Kabanjahe telah membuat SK Nomor: 1255/RSU/2016 tentang KTR. Pelaksanaan KTR di RSUD Kabanjahe sudah dimulai sejak 2009 namun kebijakan tersebut belum berhasil hingga saat ini. Pemerintah Kabupaten Karo juga belum memiliki perda tentang KTR. Hal ini lah yang menjadi salah satu faktor penghambat pelaksanaan KTR di RS di Kabupaten Karo Sekitarnya. Ketidakberhasilannya KTR di RSU Kabanjahe juga disebabkan karena kurangnya sosialisasi pihak rumah sakit kepada pengunjung dan kurangnya rambu-rambu tentang larangan KTR. Jika tidak ada upaya pengendalian kebiasaan mengkonsumsi tembakau ini, diprediksi angka kematian akibat kebiasaan merokok akan mengalami peningkatan lebih dari 8 juta jiwa setiap tahunnya dan sebanyak 80 persen dari angka kematian tersebut terjadi di negara-negara berkembang seperti Indonesia. ${ }^{5}$ Cara yang efektif saat ini untuk melakukan perlindungan dan hak kepada orang tidak perokok adalah melalui Undang-Undang atau Perda tentang KTR yang dapat memberikan perlindungan hukum. ${ }^{6}$ Lemahnya komitmen dan kepatuhan pegawai dalam merealisasikan SK direktur RSUD Kabanjahe sangat berpengaruh penting terhadap keberhasilan pelaksanan SK tersebut baik dari tingkat pimpinan sampai bawahan. Ketidakpatuhan pegawai RSUD Kabanjahe ini dibuktikan dengan masih banyaknya ditemukan pegawai merokok di lingkungan RS serta kurangnya sosialisasi kepada pengunjung RS. Sesuai dengan hasil penelitian yang dilakukan oleh Marguarite, R.R mengemukakan bahwa komitmen dan dukungan yang kuat sangat berperan penting dalam mendukung berhasilnya KTR. Bukti menunjukkan bahwa salah satu faktor yang mesukseskan implementasi kebijakan KTR di fasilitas kesehatan mental adalah dukungan konsistensi yang diberikan di seluruh tingkatan organisasi mulai dari pegawai utama hingga tingkat eksekutif. ${ }^{7}$ Pelatihan dan pembentukan pengawasan dan atau komite kerja KTR di RSUD Kabanjahe yang juga 
sampai saat ini belum terbentuk. Meskipun realisasi peraturan KTR ini sudah berjalan delapan tahun sangat berdampak terhadap ketidakefektifan penerapan KTR di RSUD Kabanjahe. Hal ini juga masih jauh dari apa yang diamanatkan dalam Pedoman Pengembangan KTR Kemenkes RI tahun 2011 yang menyatakan bahwa penyiapan infrastruktur Kawasan Tanpa Rokok (KTR) antara lain : a) Membuat surat keputusan dari pimpinan tentang penanggung jawab dan pengawas Kawasan Tanpa Rokok di fasilitas pelayanan kesehatan. b) Instrumen pengawasan. c) Materi sosialisasi penerapan Kawasan Tanpa Rokok. d) Pembuatan dan penempatan tanda larangan merokok di fasilitas pelayanan kesehatan. e) Mekanisme dan saluran penyampaian pesan di sekitar fasilitas pelayanan kesehatan. f) Pelatihan bagi pengawas Kawasan Tanpa Rokok. g) Pelatihan kelompok sebaya bagi karyawan tentang cara berhenti merokok. Ini didukung dengan penelitian yang dilakukan sebelumnya bahwa pembentukan komite kelompok kerja dan pelatihan pengawasan KTR yang belum ada menjadi salah satu penghambat berhasilnya KTR. Pentingnya mempertimbangkan penyediaan pelatihan bagi para staf untuk intervensi berhenti merokok di lingkungan rumah sakit sangat berperan penting dalam mewujudkan KTR. ${ }^{8}$ Keterlibatan dan dukungan internal rumah sakit sangat penting dalam mendukung keberhasilan KTR. ${ }^{9}$ Disamping pelatihan keefektifan penerapan KTR juga tidak lepas dari dukungan pihak rumah sakit untuk menjadi contoh dan juga sebagai cerminan dalam menerapkan KTR. ${ }^{10}$ Dukungan dan keterlibatan pegawai RS dalam pelaksanaan KTR ini berdasarkan pengamatan peneliti sangat kurang ini dibuktikan dari hasil pengamatan peneliti ada 74 orang per harinya yang masih merokok di lingkungan RS baik pegawai maupun pengunjung RS. Berdasarkan wawancara singkat dengan salah seorang pegawai RSU Kabanjahe menyatakan bahwa penerapan KTR di RSU Kabanjahe masih mencapai $30 \%$ ketidakberhasilan KTR ini juga disebabkan kuat karena ketidak patuhan pegawai dan kurangnya komitmen direktur rumah sakit. Tujuan penelitian ini dilakukan untuk menganalisis sejauh mana pengimplementasian SK Direktur RSUD Kabanjahe tentang KTR, apa yang menjadi hambatan pengimplementasiannya, serta strategi apa dilakukan supaya kebijakan KTR tersebut dapat berjalan efektif dan maksimal.

\section{METODE PENELITIAN}

Penelitian ini menggunakan metode penelitian kualitatif Metode pengumpulan data yang digunakan dalam penelitian ini adalah dengan wawancara mendalam (indepth interview), observasi serta, dokumentasi. Pengumpulan data dilakukan berhadapan secara langsung dengan narasumber. ${ }^{11}$ Penelitian ini dilakukan di RSU Kabanjahe pada rentang waktu bulan desember 2016 sampai dengan bulan mei tahun 2017. Pemilihan lokasi penelitian di RSU Kabanjahe karena rumah sakit merupakan salah satu lokasi/tempat yang harus melaksanakan kebijakan KTR. Populasi dalam penelitian ini adalah seluruh pegawai dan pengunjung rumah sakit, dan sampel adalah orang-orang yang terlibat dalam kebijakan KTR meliputi : Kepala tata usaha, Kepala bidang data dan perencanaan, Kepala bidang penunjang pelayanan medis, kepala sub bagian umum dan perlengkapan, pasien rawat inap (1 orang), Pasien rawat jalan (1 orang). Pemilihan informan dalam penelitian ini dilakukan dengan menggunakan pendekatan purposif dengan kriteria informan yang menguasai atau memahami sesuatu melalui proses enkulturasi sehingga sesuatu itu bukan sekedar diketahui tetapi juga dihayatinya, informan yang tergolong masih sedang berkecimbung atau terlibat pada kegiatan yang tengah diteliti, informan yang mempunyai waktu yang memadai untuk dimintai informasi, dan informan tidak cenderung menyampaikan informasi hasil 
"kemasannya" sendiri. Instrumen Penelitian adalah hasil wawancara direkam menggunakan alat bantu berupa alat tulis, voice recorder, dan kamera. Rekaman dari voice recorder dituliskan dalam bentuk transkrip, data dari hasil wawancara dicatat dalam bentuk tulisan-tulisan ini selanjutnya akan dirangkum dan kemudian dideskripsikan sesuai dengan data yang dibutuhkan. Analisis data menggunakan teknik analisa spradley yaitu analisis domain, analisa taksonomi, dan analisa komponensial. Pengujian data dilakukan dengan cara triangulasi : triangulasi teknik, triangulasi sumber data; dan triangulasi waktu.Kepercayaan terhadap hasil penelitian dilakukan dengan pengujian kredibilitas, depenabilitas, proses dan hasil penelitian.

\section{HASIL PENELITIAN Status Merokok dari Informan}

Status merokok yang mempengaruhi pengimplementasian kebijakan Kawasan Tanpa Rokok di RSUD Kabanjahe dapat dilihat pada tabel berikut :

Tabel 1.

Gambaran Karakteristik Responden

\begin{tabular}{|c|c|c|c|c|c|}
\hline Status di Rumah Sakit & $\begin{array}{l}\text { Jenis } \\
\text { Kelamin }\end{array}$ & $\begin{array}{l}\text { Umur } \\
\text { (Tahun) }\end{array}$ & $\begin{array}{l}\text { Pendidikan } \\
\text { Terakhir }\end{array}$ & Ket. & $\begin{array}{l}\text { Status } \\
\text { Merokok }\end{array}$ \\
\hline Kepala Tata Usaha & Perempuan & 47 & S1 & (P1) & Tidak \\
\hline $\begin{array}{l}\text { Kepala Bidang Data dan } \\
\text { Program }\end{array}$ & Laki-laki & 46 & S2 & (P2) & $\mathrm{Ya}$ \\
\hline $\begin{array}{l}\text { Kepala Bidang Penunjang } \\
\text { Pelayanan Medik }\end{array}$ & Laki-laki & 46 & S1 & (P3) & $\mathrm{Ya}$ \\
\hline $\begin{array}{l}\text { Kepala Sub Bagian Umum } \\
\text { dan Perlengkapan }\end{array}$ & Laki-laki & 53 & S1 & (P4) & $\mathrm{Ya}$ \\
\hline Pasien Rawat Inap & Laki-laki & 31 & S1 & (P5) & $\mathrm{Ya}$ \\
\hline Pasien Rawat Jalan & Laki-laki & 27 & SMA & (P6) & $\mathrm{Ya}$ \\
\hline
\end{tabular}

Berdasarkan hasil penelitian didapatkan bahwa komitmen dan kepatuhan pelaksanaan KTR melalui SK direktur RS di RSUD Kabanjahe dapat dilihat dalam tabel diatas. Tabel diatas menunjukkan bahwa dari 6 informan terdapat hanya 1 informan yang tidak merokok di lingkungan RS maupun diruangan kerja yaitu Kepala Tata Usaha/(P1) berjenis kelamin perempuan, dan 1 informan lainnya yang masih merokok diruangan kerja atau masih merokok dilingkungan RS meskipun hanya di ruangan kerja saja yaitu Kepala Bidang Penunjang Pelayanan Medik/(P3), serta 4 informan lainnya masih bebas atau tetap merokok di lingkungan rumah sakit. Pengimplementasian kebijakan
KTR di RSUD Kabanjahe secara umum belum berhasil sesuai dengan SK direktur No. 1255/SRU/2016 tentang KTR yang menetapkan bahwa : (a). Menetapkan bahwa lingkungan RSUD Kabanjahe adalah merupakan KTR, (b). Kepada seluruh pejabat di lingkungan RSUD Kabanjahe sesuai dengan kewenangannya melakukan pembinaan atas penyelenggaraan pengamanan produk tembakau sebagai zat adiktif bagi kesehatan dengan mewujudkan KTR. ${ }^{12}$

Hasil penelitian dikemukakan bahwa dukungan pelaksanaan KTR melalui SK direktur RS di RSUD Kabanjahe belum ada, baik dukungan landasan hukumnya maupun dalam aspek dukungan manajemen RS, ini 
dibuktikan dengan belum adanya Peraturan Daerah atau PERDA yang mengatur tentang KTR dan juga belum terbentuknya Komite Kerja Pengawasan KTR rumah sakit sesuai Pedoman Pengembangan KTR Kemenkes RI Tahun 2011.

\section{PEMBAHASAN}

Pada pendekatan teori implementasi oleh George C. Edward III, terdapat paling tidak 2 variabel yang sangat menentukan keberhasilan implementasi suatu kebijakan yaitu : (1). Disposisi (komitmen dan kepatuhan), dan (2). Struktur birokrasi (dukungan internal). ${ }^{13}$ Pengimplementasian KTR di RSUD Kabanjahe ini sudah berjalan selama 8 tahunatau sejak 2009, namun hingga saat ini belum berhasil atau pencapaian pelaksanaannya berdasarkan hasil wawancara dengan narasumber masih mencapai $30 \%$. Persyaratan pertama bagi implementasi kebijakan yang efektif adalah bahwa mereka yang melaksanakan kebijakan harus mengetahui apa yang mereka lakukan. Keputusan-keputusan kebijakan dan perintah harus diteruskan kepada personil yang tepat sebelum keputusan perintah itu diikuti. Untuk itu diperlukan transmisi (penyaluran) yang baik. Kejelasan yang diterima oleh pelaksana kebijakan dan kelompok sasaran sehingga tidak membingungkan dalam pelaksanaan kebijakan. ${ }^{14}$

Terobosan penting yang dilakukan oleh pemerintah baru-baru ini adalah dengan melakukan perumusan Memorandum of Understanding (MoU) antara Kementerian Dalam Negeri dan Kementerian Kesehatan yang menekankan pemberlakuan Kawasan Tanpa Rokok (KTR). Peraturan bersama antara Menteri Kesehatan dan Menteri Dalam Negeri ini dituangkan dalam surat bernomor 188/MENKES/PB/I/2011 dan Nomor 7 Tahun 2011 tentang Pedoman Pelaksanaan Kawasan Tanpa rokok. ${ }^{15}$ Sebagian besar rumah sakit di Carolina Utara telah membuat kemajuan dengan mengembangkan dan mengimplementasikan kebijakan rokok dan rokok-elektrik, dengan larangan yang cukup kuat terhadap penggunaan rokok dan rokokektrik baik di dalam atau di luar ruangan. Keberhasilan rumah sakit di Carolina dalam menerapan Kawasan Tanpa Rokok (KTR) tidak lepas dari sosialisasi yang terus-menerus dilakukan dan advokasi yang kuat lintas sektoral terkait KTR. Hal ini juga disambut positif oleh banyak rumah sakit lain yang belum memiliki kebijakan semacam itu. Meskipun informan menunjukkan bahwa kebijakan rumah sakit yang telah ada ini efektif dalam menghadapi masalah penggunaan rokok dan rokok-elektrik. Masalah-masalah kecil lainnya tetap ada terutama menyangkut keluhan dan pertanyaan dari para pengunjung rumah sakit. Hal ini menunjukkan kurangnya upaya sosialisasi kebijakan terhadap para pasien dan pengunjung rumah sakit. ${ }^{16}$

Faktor ketidak berhasilan ini disebabkan karena kurangnya komitmen dan kepatuhan direktur rumah sakit serta jajarannya yang kurang aktif melibatkan diri dalam pengimlementasian regulasi tentang KTR ini. Berdasarkan penelitian yang dilakukan di rumah sakit di Amerika mengemukakan bahwa pimpinan dan pegawai sangat berperan aktif dalam menentukan keberhasilan kebijakan rokok di rumah sakit seperti : Keterlibatan Pegawai. Keterlibatan para pegawai dalam mendukung pengendalian tembakau mulai dari sebelum dan sesudah penerapan larangan bebas asap rokok tersebut sangat berperan penting, Pengaruh dari keputusan untuk menjadikan rumah sakit bebas asap rokok. Pihak rumah sakit menemukan banyak faktor yang akhirnya mendorong mereka untuk menerapkan kebijakan bebas asap rokok. Yang paling menonjol adalah gabungan antara faktor internal dan eksternal yang berperan dalam pengambilan keputusan dan dukungan dalam penerapan bebas asap rokok, Penghalang dalam penerapan kebijakan bebas asap rokok: Penghalang internal yang utama adalah moral 
pegawai yang negatif, logika yang dimiliki oleh para pegawai yang masih banyak merokok. Sedangkan penghalang eksternal yang utama adalah kurangnya penerimaan kebijakan bebas asap rokok dari pasien dan pengunjung rumah sakit ${ }^{17}$. Hal ini dibuktikan dari hasil wawancara dari narasumber yang menyatakan masih merokok dilingkungan rumah sakit dan juga dibuktikan dengan pengamatan peneliti dimana dalam satu hari terdapat rata-rata 74 orang ditemukan masih merokok di lingkungan rumah sakit, baik pegawai maupun pasien atau keluarga pasien yang berkunjung di rumah sakit. Kurangnya komitmen pihak rumah sakit atau direktur rumah sakit beserta jajarannya dikarenakan belum ada dasar hukum yang menguatkan dari PEMDA Kabupaten Karo yaitu PERDA yang mengatur tentang KTR, sehingga dalam menjalankan kebijakan ini secara sepenuhnya tidak berjalan efektif. Kurangnya kepatuhan pegawai rumah sakit ini juga disebabkan karena belum adanya sanksi yang memberi efek jera kepada para pelanggar kebijakan KTR baik secara lisan, tulisan maupun tindakan hukum atau kebijakan-kebijakan rumah sakit laninnya. Di Skotlandia, perangkat peraturan anti rokok tahun 2006 ternyata sangat efektif dan berhasil setelah diperkenalkannya tahapan-tahapan serta kebijakan kawasan tanpa rokok di tempat umum, sehingga keuntungan dari adanya kebijakan seperti itu bisa meluas ke populasi umum, bukan hanya pada kelompok yang terpapar asap tembakau karena pekerjaannya/lingkungan kerjanya baik tempat pelayanan kesehatan, tempat ibadah, tempat bermain anak-anak dan lain-lain. ${ }^{18}$

Berdasarkan pendekatan kepatuhan dan pendekatan faktual dapat dinyatakan bahwa keberhasilan kebijakan sangat ditentukan oleh tahap implementasi dan keberhasilan proses implementasi ditentukan oleh kemampuan implementor yaitu : a) Kepatuhan implementor mengikuti apa yang diperintahkan oleh atasan, dan b. Kemampuan implementor melakukan apa yang dianggap tepat sebagai keputusan pribadi dalam menghadapi pengaruh eksternal dan faktor non organisaional, atau pendekatan faktual. ${ }^{19}$ Penelitian yang dilakukan di Rumah Sakit Malata, ketidak patuhan para pembuat kebijakan Kawasan Tanpa Rokok menjadi penghalang berhasilnya kebijakan tersebut. Prevalensi merokok diantara petugas-petugas kesehatan di rumah sakit Malta seimbang dengan masyarakat umumnya sehingga perlu tindaklanjut untuk membuat mereka berhenti merokok, selain daripada ukuran-ukuran pencegahan secara umum. Pelatihan prasarjana, dan CPD bidang pertembakauan perlu dijalankan terus. Sebagian besar petugas kesehatan mendukung bila rumah sakit umum menjadi bebas asap rokok dan melakukan promosi kesehatan. Sehingga hal ini membuka peluang bagi ukuran-ukuran pengendalian tembakau yang lebih jauh untuk memperkuat implementasi. Kenyataan di lapangan menunjukkan bahwa proporsi pegawai rumah sakit yang merokok tidaklah berbeda dengan yang ditemukan di masyarakat umum. Persentase perokok tertinggi berada pada kelompok umur termuda (18-25 tahun), padahal generasi inilah yang seharusnya paling sering terpapar pada kampanye anti rokok di sekolah atau pendidikan tersier. Kenyataan menunjukkan bahwa para perokok seringkali diberikan waktu istirahat untuk merokok secara tak resmi, hal ini bisa mengganggu usaha untuk berhenti merokok, yang mana mereka memiliki lebih banyak waktu istirahat ketimbang bekerja di bagian yang tidak terkait kegiatan merokok. Terdapat 3 area untuk merokok yang tersedia di rumah sakit, dan hal ini berdampak pada berkumpulnya para perokok di area-area tersebut untuk merokok. Hal ini mungkin dipengaruhi oleh faktor psikologi, dimana para perokok menganggap diri mereka sebagai pembangkang yang berlawanan dengan tujuan peraturan anti rokok di rumah sakit yakni untuk menurunkan jumlah perokok. Kepatuhan dan kesadaran pelaksana kebijakan KTR merupakan kunci dalam 
mewujudkan kebijakan Kawasan Tanpa Rokok. Kepatuhan dan kesadaran pelaksana ini dibuktikan dalam keberhasilan rumah sakit di Amerika. ${ }^{20}$ Dukungan pihak rumah sakit untuk menjadi contoh dan cerminan juga sangat berperan dalam mewujudkan KTR ini sesuai dengan hasil penelitian di rumah sakit Malta. $^{21}$

Dukungan internal rumah sakit dalam melakukan dan mencari strategi pengimplementasian KTR ini menjadi kunci keberhasilan yang paling tepat. Koordinasi dalam internal rumah sakit sebagai pelaku kebijakan sangat lemah jika dilihat saat ini di RSUD Kabanjahe dan juga belum ada koordinasi eksternal contohnya kepada Dinas Kesehatan Kabupaten Karo maupun LSM yang terkait dengan KTR dalam melakukan penyuluhan, sosialisasi dan edukasi lainnya kepada pegawai maupun kepada pengunjung rumah sakit. Dukungan manajemen yang masih kurang dalam mengimplementasikan kebijakan KTR di RSUD Kabanjahe juga menjadi salah satu faktor tidak terealisasinya SK direktur RSUD Kabanjahe ini secara efektif. Kegagalan dalam implementasi sering terjadi karena staf tidak mencukupi, tidak memadai atau pun tidak kompeten di bidangnya, penambahan jumlah staf dan implementor saja tidak mencukupi tetapi diperlukan pula kecukupan staf dengan keahlian dan kemampuan yang diperlukan dalam mengimplementasikan kebijakan atau melaksanakan tugas yang diinginkan oleh kebijakan atau program itu sendiri. ${ }^{21}$ Manajemen rumah sakit sangat penting dalam mendukug KTR ini, salah satu dukungan mendasar yang dapat dijadikan sebagai pedoman adalah Pedoman Pengembangan KTR Kemenkes RI Tahun 2011 yang menyatakan bahwa penyiapan infrastruktur Kawasan Tanpa Rokok (KTR) antara lain : (a). Membuat surat keputusan dari pimpinan tentang penanggung jawab dan pengawas Kawasan Tanpa Rokok di fasilitas pelayanan kesehatan. (b). Instrumen pengawasan. (c). Materi sosialisasi penerapan
Kawasan Tanpa Rokok. (d). Pembuatan dan penempatan tanda larangan merokok di fasilitas pelayanan kesehatan. (e). Mekanisme dan saluran penyampaian pesan di sekitar fasilitas pelayanan kesehatan. (f). Pelatihan bagi pengawas Kawasan Tanpa Rokok. (g). Pelatihan kelompok sebaya bagi karyawan tentang cara berhenti merokok. Seharusnya jika tahap-tahap ini dilaksanakan misalnya mulai dari sosialisasi dan pembinaan, pembentukan komite kerja dan pengawasan hingga dalam pemberian sanksi administratif pengaplikasian regulasi KTR ini berjalan efektif. Ini didukung dengan hasil penelitian yang dilakukan di Kanada sebagai strategi keberhasilan rumah sakit dalam menerapkan kebijakan bebas asap rokok adalah.Untuk memaksimalkan keberhasilan kebijakan properti rumah sakit bebas asap rokok, maka perlu diperlukan perlakuan-perlakuan yang tidak melibatkan zat tembakau baik pada pegawai RS maupun pasien, perlu dikurangi pengecualian-pengecualian kebijakan yang ada, dan perlu dikurangi pula area-area tertentu yang masih menjadi tempat merokok, Kepemimpinan yang kuat dan dukungandukungan kebijakan yang memadai.

Di Skotlandia, perangkat peraturan anti rokok tahun 2006 ternyata berhubungan dengan menurunnya rate penyakit pernapasan secara berturut-turut pada populasi di luar dari kelompok yang terpapar asap tembakau karena pekerjaannya/lingkungan kerjanya. Hasil studi menunjukkan bahwa terdapat penurunan rate perawatan asma pada anak setelah diperkenalkannya kebijakan tanpa asap rokok di tempat umum, sehingga keuntungan dari adanya kebijakan seperti itu bisa meluas ke populasi umum, bukan hanya pada kelompok yang terpapar asap tembakau karena pekerjaannya/lingkungan kerjanya. ${ }^{22}$ Kebijakan pengendalian tembakau di Indonesia masih menimbulkan perdebatan yang panjang, mulai dari hak asasi seorang perokok, fatwa haram merokok di tempat umum sampai dengan dampak anti rokok terhadap perekonomian dan tenaga kerja di 
Indonesia. Kebijakan merupakan cara yang efektif untuk mengendalikan tembakau atau lebih khusus lagi untuk mengurangi kebiasaan merokok. ${ }^{23}$ Komunikasi yang dibangun selama ini diinternal rumah sakit maupun lintas eksternal sangat lemah \& mempengaruhi ketidakberhasilan kebijakan KTR. Advokasi dan komunikasi yang efektif dapat berhasil bila dapat mempengaruhi pembuatan kebijakan dan implementasinya terhadap para stakeholder primer, mitra, maupun pelaksana. Identifikasi dan analisis kepentingan stakeholders merupakan langkah awal dalam pelaksanaan advokasi dan komunikasi. Hasil dari analisis stakeholder ini dapat memberikan asupan untuk teknik yang akan dipilih dalam memberikan advokasi dan komunikasi. Pemilihan bahan yang digunakan dalam melakukan advokasi dan komunikasi juga merupakan hal yang menentukan keberhasilan pelaksanaan advokasi dan komunikasi. ${ }^{24}$ Studi yang dilakukan di Rumah
Sakit Pendidikan Catalan Spanyol menunjukkan keefektifan UU terbaru Spanyol tentang pengendalian tembakau (UU No. 42/2010) terhaadap penurunan angka kasus perokok yang dikombinasikan dengan jaringan inisiatif rumah sakit pendidikan Catalan untuk menerapkan bebas asap rokok sangat efektif. Peneliti menemukan tingkat pelanggaran yang lebih rendah untuk semua lokasi setelah pelaksanaan UU terbaru tersebut sangat menurun dibandingkan dengan tingkat yang diperoleh pada tahun sebelumnya 2009. Dukungan penuh terhadap kebijakan di suatu rumah sakit menjadi salah satu indikator penting dalam mewujudkan keberhasilan kawasan tanpa rokok. ${ }^{25}$

Berdasarkan hasil seluruh wawancara dari narasumber disimpulkan bahwa strategi yang tepat dan efektif dalam pengimplementasian regulasi atau kebijakan KTR di RSUD Kabanjahe dapat dilihat pada gambar 1 berikut :

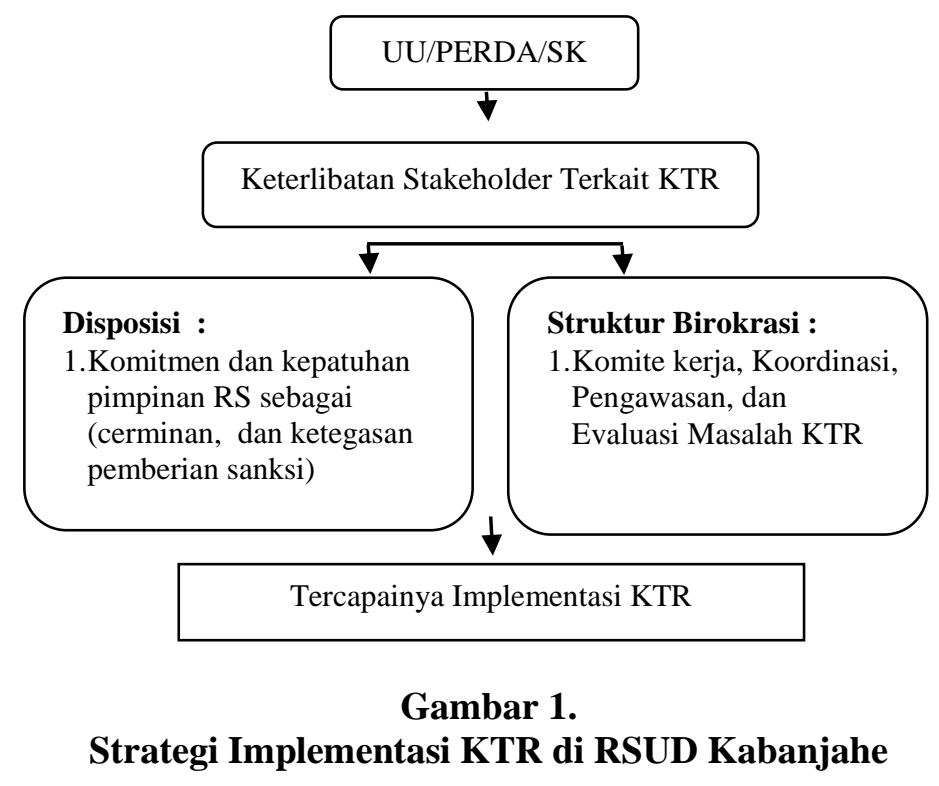


Berdasarkan gambar 1, maka strategi yang efektif dalam menerapkan kebijakan KTR di RSU Kabanjahe dapat dilakukan dengan tahap-tahan berikut :

1. Adanya Perda/Perbub yang mengatur tentang KTR sangat penting dan merupakan kunci paling utama dalam mencapai keberhasilan implementasi KTR.

2. Komitmen dan kepatuhan pelaksana kebijakan dalam pengimplementasian kebijakan KTR sangat berpengaruh dan merupakan dukungan yang esensial untuk mewujudkan KTR.

3. Sosialisasi secara berjenjang dan berkesinambungan baik kepada pegawai maupun kepada pengunjung rumah sakit atau keluarga pasien merupakan hal yang paling utama dalam mewujudkan keefektifan implementasi kebijakan KTR.

4. Pembentukan tim kelompok kerja pengawasan kebijakan KTR, dan pemberian sanksi kepada pelanggar kebijakan KTR merupakan cara yang efektif dalam pengimplementasian kebijakan KTR.

5. Peningkatan koordinasi yang kuat lintas sektoral yaitu: Pemda, Dinkes, dan LSM lain yang berkaitan dengan KTR.

\section{DAFTAR PUSTAKA}

1. Tobacco Control Support Centre (TCSC). Kawasan Tanpa Rokok dan Implementasinya - policy paper Seri 4. Jakarta: TCSC. 2012.

2. WHO Framework Convention on Tobacco Control. 2014 Sep 22

3. Undang-undang Republik Indonesia Nomor 44 Tahun 2009 Tentang Rumah Sakit.

4. Undang-undang Republik Indonesia Nomor 36 Tahun 2009 Tentang Kesehatan.

5. WHO-Tobacco Free Initiative. Perlindungan Terhadap Paparan Asap Rokok Orang Lain

\section{KESIMPULAN DAN SARAN}

Komitmen dan kepatuhan serta dukungan pelaku para kebijakan menjadi kunci utama dalam keberhasilan pengimplementasian kebijakan KTR di rumah sakit. Pembentukan komite atau kelompok serikat kerja khusus penyusunan kebijakan terkait KTR yang mengatur tentang sosialisasi, penindakan atau pemberian sanksi kepada pelanggar kebijakan KTR hingga pembinaan dan evaluasi yang juga sesuai dengan pedoman pengembangan KTR di rumah sakit yang dikeluarkan Kemenkes RI Tahun 2011 menjadi dasar regulasi pengimplementasian KTR di rumah sakit serta koordinasi, advokasi lintas sektor organisasi yang berkaitan dengan KTR, pemantauan dan evaluasi masalah KTR yang berkesinambungan.

Adapun saran untuk perbaikan dalam mengimplementasikan kebijakan KTR di RSU Kabanjahe adalah : (1). Pimpinan rumah sakit beserta jajarannya agar menjadi contoh dan cerminan sebagai pelaku kebijakan KTR di lingkungan rumah sakit, dan pembentukan tim komite atau kelompok kerja penyusunan kebijakan KTR sehingga pengimplementasiannya baik dalam memonitoring, memberikan sanksi dapat berjalan efektif, serta meningkatkan advokasi, koordinasi lintas sektor atau pihak-pihak yang berkaitan dengan kebijakan Kawasan Tanpa Rokok.

(Kawasan Tanpa Rokok) - Tobacco Intiative Bab 8. Jakarta: TFI. 2010.

6. Tobacco Control Support Centre (TCSC). Kawasan Tanpa Rokok dan Implementasinya - policy paper Seri 4. Jakarta: TCSC. 2012.

7. Marguerite, R.R. "Smoke-free mental health inpatient facility policies in Australia variation across states and territories". Australian and New Zealand Journal of Public Health. 2017.

8. Adanna, Lisa, Bedour. "Smoking, attitudes to smoking and provision of smoking cessation advice in two teaching hospitals in Ireland: 
do smoke-free policies matter". Journal Health Psychology and Behavioral Medicine, 2015. Vol. 3, No. 1, 142-153.

9. Kerrie. "Are Canadian hospitals leading by example to promote smoke-free hospital properties? Rationale, challenges and opportunities. Journal of Hospital Administration. 2016. Vol. 5, No. 4.

10.Joëlle, Sarah, Luisa. "Barriers to implement a smoke free hospital. What action should be taken". Journal Malta Medical. 2014. Volume 26 Issue 032014.

11. Sugiyono. Metode Penelitian Kuantitatif dan kualitatif, Bandung : Alfabeta. 2012.

12. Surat Keputusan Direktur RSU Kabanjahe No. 1255/RSU/2016. Tentang Kawasan Tanpa Rokok (KTR).

13.William, Dunn. Pengantar Analisis Kebijakan Publik (terjemahan), Yogyakarta, Gajahmada University press. 2003.

14.Winarno, Budi. Teori dan Proses Kebijakan Publik. Yogyakarta: Media Pressindo. 2002.

15.Kemenkes RI. Peraturan Bersama Menteri Kesehatan dan Menteri dalam Negeri RI Nomor 188/ PB/I/ 2011 atau Permenkes Nomor 7 Tentang Pedoman Pelaksanaan Kawasan Tanpa Rokok, Jakarta. 2011.

16.Clare, Hannah, Baker. "Electronic Cigarettes on Hospital Campuses. International Journal of Environmental Research and Public Health. 2015. Diakses: 29 December 2015

17.http://tobaccocontrol.bmj.com/ smoke-free worksites, hospitals, United States. Diakses May 23, 2017.

18.Daniel, Sally, Jon. "Smoke-free Legislation and Hospitalizations for Childhood Asthma. The New England Journal of Medicine. 2010. Diakses 16 September 2010.

19.Agustino. Dasar-Dasar Kebijakan Publik, Bandung : Alfabeta. 2006.

20.Daniel, Mary, Robin. "Implementing smoking bans in American hospitals: results of a national survey. http://tobaccocontrol.bmj.com. 2017. Diakses 23 Mei 2017.

21.Indiahono. Kebijakan Publik Berbasis Dynamic Policy analisy., Yokyakarta : Gaya Media. 2009.

22.Daniel Mackay, Sally Haw. "smoke free legislation and hospitalizations for childhood asthma", The New Englang Journal of Medicine. 2017. Diakses 22 Mey 2017.

23.Prabandari. Kawasan Tanpa Rokok sebagai Alternative Pengendalian Tembakau Studi Efektivitas Penerapan Kebijakan Kampus Bebas Rokok terhadap Perilaku dan Status Merokok Mahasiswa di Fakultas Kedokteran UGM. Jurnal Manajemen Pelayanan Kesehatan. 2009. Vol. 12(04): 218-225.

24.Iswarno. Analisis Untuk Penerapan Kebijakan " Analisis Stakeholder dalam Kebijakan Program Kesehatan Ibu dan Anak di Kabupaten Kapahiang”. Jurnal Kebijakan Kesehatan Indonesia. 2013.

25.Xisca Sureda, Montse Ballbe. 'Impact of tobacco control policies in hospitals: Evaluation of a nationl smoke free", Journal homepage: http://ees.elsevier.com/pmedr. Second-hand smoke Particulate matter Smoke-free campuses Hospitals Tobacco smoke pollution, 2014. Diakses 1 November 2014. 